\title{
Kajian Komparatif Sebelum Dan Pasca Launching Samsat Keliling Dan Samsat Corner Mall Terhadap Penerimaan Pajak Kendaraan Bermotor Di Provinsi Sumatera Selatan
}

\author{
Iwan Efriandy ${ }^{\mathrm{a}, 1, *}$, Meita Rahmawati ${ }^{\mathrm{b}, 2}$, Efva Octavina Donata ${ }^{\mathrm{b}, 3}$ \\ ${ }^{\mathrm{a}, \mathrm{b}}$ Universitas Sriwijaya \\ ${ }^{1}$ iwanefriandy@unsri.ac.id *; ${ }^{2}$ Meita_rahmawati@unsri.ac.id; ${ }^{3}$ efvagozali@unsri.ac.id \\ * corresponding author
}

\section{ARTICLE INFO}

Keywords

Vehicle Tax;

The Mobile of One-sop

Administration Service

Office (SAMSAT);

SAMSAT Corner Mall

\begin{abstract}
The South Sumatera Government wants to achieve the targets set in the Local Own-source Revenue (LOR), of which 40 percent comes from the motor vehicle tax and motor vehicle transfer fees. However, the LOR revenue target through vehicle tax and motor vehicle transfer fees set in 2016 only reached around 50 to 60 percent. In an effort to improve services that get closer to the community and increase the collection of vehicle tax in order to achieve the LOR targets in South Sumatera Province, the Provincial Government has launched a special mobile One-stop Administration Services Office (SAMSAT) in 21 Regional Technical Implementation Unit (UPTD) SAMSAT in 17 districts/cities and SAMSAT corner mall which is in 4 malls in Palembang city.

The study aims to examine and analyze whether there are significant differences before and after the launching of mobile One-Stop Administration Service Office and SAMSAT corner mall on Vehicle Tax Revenue of South Sumatra Province
\end{abstract}

\section{PENDAHULUAN}

Pelaksanaan pembangunan nasional di tingkat pusat dan daerah berkesinambungan dan secara terus menerus membutuhkan adanya pembiayaan pembangunan, baik yang berasal dari penerimaan dalam negeri maupun pinjaman dari luar negeri. Pembangunan yang hanya mengandalkan pinjamaan dari luar negeri, akan mempunyai dampak yang sangat besar bagi stabilitas keuangan negara dan juga masyarakat. Dalam hal mengurangi ketergantungan pembiayaan pembangunan nasional yang berasal dari negara funding. Pemerintah harus mempunyai potensi sumber pendapatan negara yang besar. Sumber pendapatan negara berasal dari penerimaan perpajakan dan penerimaan negara bukan pajak (PNBP). Sumber pendapatan negara yang utama saat ini berasal dari pajak.

Berdasarkan Undang-Undang Republik Indonesia Nomor 6 Tahun 1983 tentang Ketentuan Umum dan Tata Cara Perpajakan sebagaimana telah diubah dengan perubahan ketiga dengan Undang-Undang Republik Indonesia Nomor 28 Tahun 2007, dan perubahan keempat UndangUndang Republik Indonesia Nomor 16 Tahun 2009, pajak adalah kontribusi wajib kepada negara yang terutang oleh pribadi atau badan yang bersifat memaksa berdasarkan undang-undang, dengan tidak mendapatkan imbalan secara langsung dan digunakan untuk keperluan negara bagi sebesarbesarnya kemakmuran rakyat. Pemunggutan pajak menurut lembaga pemunggutnya terdiri dari pajak pusat yang dipungut oleh pemerintah pusat dan digunakan untuk membiayai rumah tangga negara dan pajak daerah dipunggut pemerintah daerah dan digunakan untuk membiayai rumah tangga daerah. Sumber pendapatan daerah dapat diharapkan menjadi sumber pembiayaan penyelenggaraan pemerintahan dan pelaksanaan pembangunan, dan juga kegiatan kemasyarakatan di daerah untuk meningkatkan dan memeratakan kesejahteraan rakyat.

Sesuai dengan Undang-Undang Republik Indonesia Nomor 2 Tahun 1999 tentang Pemerintahan Daerah dan Undang-Undang Republik Indonesia Nomor 12 Tahun 2008 Pasal 157 tentang Otonomi Daerah, dan telah diubah menjadi Undang-Undang Republik Indonesia Nomor 28 
Tahun 2009 Pasal 1 Angka 10 tentang Pajak Daerah dan Retribusi Daerah, pengertian Pajak Daerah adalah kontribusi Wajib Pajak kepada daerah yang terutang oleh pribadi atau badan yang bersifat memaksa berdasarkan Undang-Undang, dengan tidak mendapatkan imbalan secara langsung dan digunakan untuk keperluan daerah bagi sebesar-besarnya kemakmuran rakyat.

Pajak daerah terdiri dari dari pajak provinsi dan pajak kabupaten/kota yang pengelolaan pajak daerah dilakukan oleh pemerintah daerah baik di tingkat provinsi maupun kabupaten/kota. Pajak Provinsi terdiri dari Pajak Kendaraan Bermotor (PKB) dan Pajak Bea Balik Nama Kendaraan Bermotor (BBN-KB), Pajak Bahan Bakar Kendaraan Bermotor (PBB-KB), Pajak Air Permukaan (PAP) dan Pajak Rokok.

Pemerintah Provinsi Sumatera Selatan mengeluarkan Peraturan Daerah Provinsi Sumsel Nomor 3 Tahun 2011 dan Peraturan Gubernur Nomor 11 Tahun 2012 dijelaskan bahwa pajak daerah merupakan sumber pendapatan daerah yang penting guna mendanai penyelenggaraan pemerintahan dan pelaksanaan pembangunan. Pendapatan Asli Daerah (PAD) sebagai potensi utama pembangungan daerah dan sangat diperlukan daerah guna penyelenggaraan pemerintahan. Sumber Pendapatan Asli Daerah (PAD), terdiri dari hasil pajak daerah, hasil retribusi daerah, hasil Perusahaan Milik Daerah dan hasil pengelolaan kekayaan daerah, dan lain-lain Pendapatan Asli Daerah yang sah.

Pajak Kendaraan Bermotor (PKB) dan Pajak Bea Balik Nama Kendaraan Bermotor (BBN-KB) merupakan tulang punggung salah satu sumber PAD Provinsi Sumatera Selatan. Pertumbuhan jumlah kendaraan bermotor di Provinsi Sumatera Selatan terus mengalami peningkatan dari tahun ke tahun, terutama jenis sepeda motor.

Badan Pendapatan Daerah (Bapenda) Provinsi Sumatera Selatan merupakan unsur penunjang pemerintahan yang menjadi kewenangan Pemerintah Provinsi Sumatera Selatan di bidang keuangan sub sektor pendapatan daerah. Dalam rangka upaya untuk meningkatkan pendapatan daerah (PATDA), Bapenda Provinsi Sumatera Selatan telah banyak melakukan upaya-upaya untuk mengoptimalkan target realisasi PATDA, diantaranya mengoptimalisasikan PAD dari penarikan Pajak Kendaraan Bermotor (PKB).

Dalam rangka meningkatkan target realisasi PAD, berbagai upaya telah dilakukan Pemerintahan Daerah Provinsi Sumatera Selatan melalui Dispenda Provinsi Sumatera Selatan, salah satunya mengoptimalkan penerimaan dari penagihan Pajak Kendaraan Bermotor (PKB), Bea Balik Nama Kendaraan Bermotor (BBN-KB) dan mengelar Program pemutihan pajak kendaraan bermotor.

Pada tanggal 5 April 2017 Pemerintah Provinsi Sumatera Selatan bersama Dirlantas Polda Sumsel, PT Jasa Raharja (Persero) Cabang Sumsel dan Bank Sumsel Babel telah melakukan launching Samsat Keliling, Samsat Corner Mall dan Samsat Payment Point Bank Sumsel Babel (BSB) dan Samsat Desa/Kelurahan, untuk mengakomodir niat baik masyarakat yang ingin melakukan pembayaran pajak kendaraan roda dua/roda empat (R2/R4).

Target penerimaan PAD melalui PKB dan BBNKB yang ditetapkan tahun 2016 lalu baru mencapai sekitar 50 sampai 60 persen. "Kita berharap melalui pelayanan ini dapat memberikan kemudahan bagi kemudahan bagi masyarakat dan tercapainya target-target pendapatan daerah Provinsi Sumatera Selatan melalui penerimaan pajak di 21 UPTD Samsat di 17 Kabupaten/Kota (Plt. Sekretaris Daerah Provinsi Sumsel: http://mediaindonesia.com). Tabel 1.3 berikut ini mengambarkan target dan realisasi penerimaan pajak kendaraan bermotor (PKB) Provinsi Sumatera Selatan.

Tabel 1. Target dan Realisasi Penerimaan Pajak Kendaaran Bermotor (PKB) Kabupaten/Kota di Sumatera Selatan

\begin{tabular}{|c|cc|ll|c|}
\hline Tahun & \multicolumn{2}{|c|}{ Target } & \multicolumn{2}{c|}{ Realisasi } & \% \\
\hline 2016 & $\mathrm{Rp}$ & 1.033 .013 .683 .981 & $\mathrm{Rp}$ & 847.081 .975 .441 & 82 \\
\hline 2017 & $\mathrm{Rp}$ & 850.000 .000 .000 & $\mathrm{Rp}$ & 873.456 .322 .575 & 102 \\
\hline 2018 & $\mathrm{Rp}$ & 878.645 .000 .000 & $\mathrm{Rp}$ & 970.473 .167 .519 & 110 \\
\hline
\end{tabular}

Sumber: Bapenda Provinsi Sumsel (2019) 
Berdasarkan tabel 1, di atas, sejak di launching pada tahun 2017 program pelayanan penghimpunan pajak kendaraan bermotor samsat keliling, samsat corner mall dan samsat payment point Bank Sumsel Babel (BSB), menunjukkan peningkatan jumlah penerimaan pajak kendaraan bermotor (PKB) melebihi pencapaian di atas target-target yang telah ditetapkan oleh Pemerintah Daerah Provinsi Sumatera Selatan.

Berbagai latar belakang penelitian diatas, penulis tertarik untuk meneliti yaitu mengenai bagaimana sebelum dan pasca launching samsat keliling dan samsat corner mall berpengaruh terhadap penerimaan pajak kendaraan bermotor (PKB) di Provinsi Sumatera Selatan.

\section{KAJIAN PUSTAKA}

\section{Teori Yang Mendukung Pemungutan Pajak}

Menurut Brotodiharjo (dalam Halim, Bawono dan Dara, 2014), beberapa teori yang memberikan pembenaran kepada negara untuk hak memungut pajak, diantaranya adalah sebagai berikut:

a. Teori Kepentingan

Teori ini menekankan pembebanan pajak pada penduduk seluruhnya harus didasarkan atas kepentingan orang masing-masing dalam tugas negara/pemerintah (yang bermanfaat baginya), termasuk juga perlindungan atas jiwa orang-orang itu serta harta bendanya.

b. Teori Daya Pikul

Teori daya pikul mengandung suatu kesimpulan bahwa dasar keadilan dalam pemunggutan pajak adalah terletak pada jasa-jasa yang diberikan oleh negara kepada warganya, yaitu perlindungan atas jiwa dan harta bendanya.

c. Teori Bakti

Teori ini didasarkan pada paham organisasi negara yang mengajarkan bahwa negara sebagai organisasi mempunyai tugas untuk menyelenggarakan kepentingan umum.

\section{Tinjauan Pajak dari Berbagai Aspek}

Menurut Waluyo (2008), pajak dapat dapat ditinjau dari berbagai aspek.

a. Aspek Ekonomi

Pajak merupakan penerimaan negara yang digunakan untuk mengarahkan kehidupan masyarakat menuju kesejahteraan. Pajak sebagai motor penggerak kehidupan ekonomi masyarakat.

b. Aspek Hukum

Pajak merupakan masalah keuangan negara. Dasar yang digunakan pemerintah untuk mengatur masalah keuangan negara, yaitu Pasal 23A Amandemen UUD 1945 (Pajak dan punggutan lain yang bersifat memaksa untuk keperluan negara diatur dengan undang-undang).

c. Aspek Keuangan

Pajak dipandang bagian yang sangat penting dalam penerimaan negara. Jika dilihat dari penerimaan negara, kondisi keuangan negara tidak lagi semata-mata dari penerimaan negara berupa minyak dan gas bumi, tetapi lebih berupaya untuk menjadikan pajak sebagai primadona penerimaan negara.

d. Aspek Sosiologi

Pajak ditinjau dari segi masyarakat, yaitu menyangkut akibat atau dampak terhadap masyarakat atas punggutan dan hasil apakah yang dapat disampaikan kepada masyarakat.

\section{Pengertian Pajak}

Undang-Undang Republik Indonesia Nomor 6 Tahun 1983 tentang Ketentuan dan Tata Cara Perpajakan sebagaimana telah diubah dengan perubahan ketiga dengan Undang-Undang Republik 
Indonesia Nomor 28 Tahun 2007, dan perubahan keempat Undang-Undang Republik Indonesia Nomor 16 Tahun 2009 Pasal 1 Angka 1, menyatakan pajak adalah kontribusi wajib pajak kepada negara yang terutang oleh orang pribadi atau badan yang bersifat memaksa berdasarkan Undang-Undang, dengan tidak mendapatkan imbalan secara langsung dan digunakan untuk keperluan negara dan sebesar-besarnya kemakmuran rakyat.

\section{Fungsi Pajak}

Menurut Sambodo (2015), pajak memiliki 5 (lima) fungsi, yaitu:

a. Fungsi Penerimaan (budgetair)

b. Fungsi Mengatur (reguleren)

c. Fungsi Stabilitas

d. Fungsi Redistribusi Pendapatan

e. Fungsi Demokrasi

\section{Pajak dan Jenis Pungutan Lainnya}

Menurut Waluyo (2008), jenis-jenis pungutan yang dilakukan oleh pemerintah selain pajak adalah sebagai berikut:

a. Retribusi

Retribusi pada umumnya mempunyai hubungan langsung dengan kembalinya prestasi, karena pembayaran tersebut ditunjukkan semata-mata untuk mendapatkan suatu prestasi dari pemerintah.

b. Sumbangan

Sumbangan seseorang yang menikmati prestasi justru tidak dapat ditunjuk, tetapi golongan tertentu yang dapat menikmati kontraprestasi, misalnya sumbangan bencana alam.

\section{Jenis Pajak}

Menurut Halim, Bawono dan Dara (2014), jenis pajak dikelompokkan ke dalam 3 (tiga) bagian, yaitu:

a. Pajak Menurut Golongannya

1. Pajak Langsung, yaitu pajak yang harus ditanggung sendiri oleh Wajib Pajak dan pembebananya tidak dapat dilimpahkan kepada pihak lain. Contoh: pajak penghasilan $(\mathrm{PPh})$

2. Pajak Tidak Langsung, yaitu pajak yang pembebananya dapat dilimpahkan kepada pihak lain. Contoh: pajak pertambahan nilai (PPN)

b. Pajak Menurut Sifatnya

1. Pajak Subjektif, yaitu pajak yang berpangkal atau berdasarkan pada subjeknya, dan selanjutnya dicari syarat objektifnya, dalam arti memperhatikan keadaan diri Wajib Pajak.

Contoh: pajak penghasilan $(\mathrm{PPh})$

2. Pajak Objektif, yaitu pajak yang berdasarkan pada objeknya, tanpa memperhatikan keadaan diri Wajib Pajak.

Contoh: pajak pertambahan nilai (PPN)

c. Pajak Menurut Lembaga Pemungutnya

1. Pajak Pusat, yaitu pajak yang dipungut oleh pemerintah pusat dan digunakan untuk membiayai rumah tangga negara.

Contoh: pajak penghasilan (PPh), pajak pertambahan nilai (PPN) dan pajak penjualan atas barang mewah (PPN-BM)

2. Pajak Daerah, yaitu pajak yang dipungut oleh pemerintah daerah dan digunakan untuk membiayai rumah tangga daerah. Pajak daerah terdiri dari:

a. Pajak Provinsi, contoh: pajak kendaraan bermotor (PKB), pajak bahan bakar kendaraan bermotor, dan pajak air permukaan.

b. Pajak Kabupaten/Kota, contoh: pajak reklame, pajak penerangan jalan, dan pajak hiburan.

\section{Pajak Daerah}

Menurut Undang-Undang Republik Indonesia Nomor 28 Tahun 2009 tentang Pajak Daerah dan 
Retribusi Daerah Pasal 1Angka 10, pajak daerah adalah kontribusi wajib kepada Daerah yang terutang oleh pribadi atau badan yang bersifat memaksa berdasarkan Undang-Undang, dengan tidak mendapatkan imbalan secara langsung dan digunakan untuk keperluan Daerah bagi sebesarbesarnya kemakmuran rakyat.

\section{Jenis Pajak Daerah}

Jenis pajak daerah yang diterapkan di Indonesia, sesuai dengan Undang-Undang Republik Indonesia Nomor 28 Tahun 2009 tentang Pajak Daerah dan Retribusi Daerah Pasal 1 Angka 1 dan 2 dibagi menjadi 2(dua) jenis, yaitu:

a. Jenis Pajak Provinsi, terdiri atas:

1. Pajak Kendaraan Bermotor (PKB)

2. Bea Balik Nama Kendaraan Bermotor (BBNKB)

3. Pajak Bahan Bakar Kendaraan Bermotor

4. Pajak Air Permukaan

5. Pajak Rokok

b. Jenis Pajak Kabupaten/Kota, terdiri dari:

1. Pajak Hotel

2. Pajak Restoran

3. Pajak Hiburan

4. Pajak Reklame

5. Pajak Penerangan Jalan

6. Pajak Mineral Bukan Logam dan Batuan

7. Pajak Parkir

8. Pajak Air Tanah

9. Pajak Sarang Burung Walet

10. Pajak Bumi dan Bangunan Perdesaan dan Perkotaan

11. Bea Perolehan Hak atas Tanah dan Bangunan (BPHTB).

Menurut Pasal 2 Angka 4 Undang-Undang Republik Indonesia Nomor 28 Tahun 2009 tentang Pajak Daerah dan Retribusi Daerah, jenis pajak sebagaimana dimaksud pada Pasal 2 Angka 1 dan Angka 2, dapat tidak dipunggut apabila potensinya kurang memadai dan/atau disesuaikan dengan kebijakan daerah yang ditetapkan dengan Peraturan Daerah.

\section{Pajak Kendaraan Bermotor}

Pajak kendaraan bermotor (PKB), termasuk ke dalam jenis pajak provinsi, yang merupakan bagian dari Pajak Daerah. Lebih lanjut Pajak Kendaraan Bermotor sebagaimana yang didefinisikan Pasal 1 Angka 12 Undang-Undang Republik Indonesia Nomor 28 Tahun 2009 tentang Pajak Daerah dan Retribusi Daerah adalah pajak atas kepemilikan dan/atau penguasaan kendaraan bermotor.

Dalam pelaksanaan pemungutannya dilakukan di kantor bersama samsat. Kantor bersama samsat ini melibatkan 3 (tiga) instansi pemerintah, yaitu: Badan Pendapatan Daerah (Bapenda), Kepolisian Daerah Republik Indonesia (Polda) dan PT. Jasa Raharja (Persero).

\section{Sistem Administrasi Manunggal Satu Atap (Samsat)}

Sistem administrasi manunggal satu atap (Samsat) atau dalam Bahasa Inggris, one roof system adalah suatu sistem administrasi yang dibentuk untuk memperlancar dan mempercepat pelayanan kepentingan masyarakat yang kegiatannya diselenggarakan dalam satu gedung. Contoh dari samsat adalah dalam pengurusan dokumen kendaraan bermotor.

Samsat merupakan suatu sistem kerjasama secara terpadu antara Kepolisian Republik Indonesia (Polri) dalam hal ini Kepolisian Daerah (Polda), Badan Pendapatan Daerah (Bapenda) Provinsi, dan PT Jasa Raharja (Persero) dalam pelayanan untuk menerbitkan Surat Tanda Nomor Kendaraan (STNK) dan Tanda Nomor Kendaraan Bermotor (TNKB) yang dikaitkan dengan pemasukan uang ke kas negara, baik melalui Pajak Kendaraan Bermotor (PKB), Bea Balik Nama Kendaraan Bermotor (BBN-KB), dan Sumbangan Wajib Dana Kecelakaan Lalu Lintas Jalan (SWDKLLJ). 
Dalam hal ini, Polri memiliki fungsi penerbitan STNK dan Dispenda Provinsi menetapkan besarnya Pajak Kendaraan Bermotor (PKB) dan Bea Balik Nama Kendaraan Bermotor (BBN-KB), sedangkan PT Jasa Raharja (Persero) mengelola Sumbangan Wajib Dana Kecelakaan Lalu Lintas Jalan (SWDKLLJ).

Lokasi Kantor Bersama Samsat umumnya berada di lingkungan Kantor Polri setempat, atau di lingkungan Satuan Lalu Lintas (Satlantas/Ditlantas) Polda setempat.

\section{Layanan Samsat}

Layanan samsat diberikan dengan tujuan untuk meningkatkan mutu pelayanan publik, memperlancar dan mempercepat pelayanan kepentingan masyarakat, khususnya pelayanan pembayaran pajak kendaraan bermotor (PKB). Beberapa layanan samsat diantaranya:

\section{a. Samsat Keliling}

Layanan pengesahan STNK setiap tahun, pembayaran PKB dan SWDKLLJ di dalam kendaraan dengan metode jemput bola, yaitu dengan mendatangi pemilik kendaraan/Wajib Pajak yang jauh dari pusat pelayanan Samsat.

\section{b. Samsat Corner}

Merupakan inovasi pada pelayanan publik, khususnya pelayanan pembayaran PKB/pengesahan STNK satu tahun, dimana Wajib Pajak diberikan kemudahan dan kepastian tentang sistem dan prosedur layanan. Samsat corner dialokasikan pada mekanisme layanan Samsat Induk tapi khusus untuk Pelayanan Pengesahan STNK setiap tahun.

Gambar 1. Rerangka Pemikiran

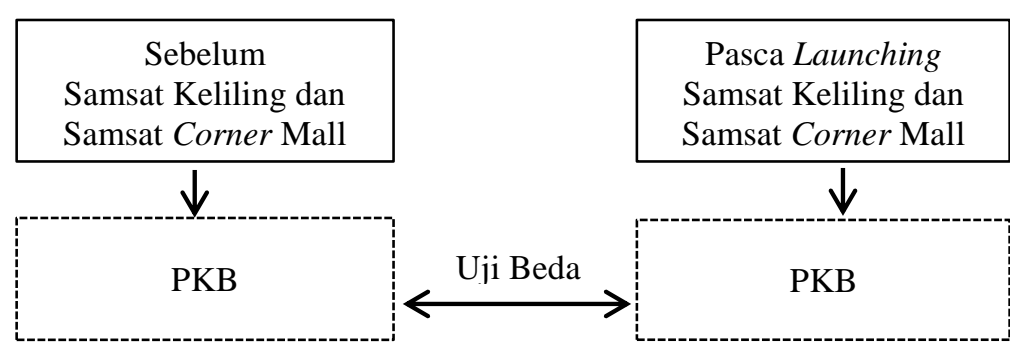

Sumber: Hasil Olahan Penulis (2019)

\section{METODE PENELITIAN}

\section{Teknik Pengumpulan data}

Data dalam penelitian ini dikumpulkan dengan cara mendokumentasikan dari Badan Pendapatan Daerah (Bapenda) Provinsi Sumatera Selatan. Data yang gunakan adalah data kuantitatif dan data sekunder. Data yang kumpulkan adalah data realisasi penerimaan pajak kendaraan bermotor (PKB) sebelum dan pasca launching samsat keliling dan samsat corner mall.

\section{Populasi dan Sampel}

Populasi penelitian adalah pajak kendaraan bermotor. Objek penelitian adalah Kabupaten dan Kota di wilayah Sumatera Selatan, yang terdiri dari 11 (sebelas) pemerintah kabupaten dan 4 (empat) pemerintah kota. Sampel yang digunakan dalam penelitian ini adalah pajak kendaraan bermotor. Data penelitian meliputi data tahun 2016 dan tahun 2018. Data tahun 2017 tidak dimasukkan sebagai sampel dikarenakan launching mobil khusus pelayanan (samsat keliling) dan samsat corner mall serta payment point Bank Sumsel Babel (BSB) baru dilakukan pada April 2017.

\section{Model Penelitian}

Penelitian ini menggunakan kerangka penelitian berupa pengujian atas variabel $\mathrm{X}$ (independen) terhadap variabel Y (dependen). Variabel independen yang dimaksud adalah samsat keliling dan samsat corner mall. Sementara variabel dependen berupa pajak kendaraan bermotor (PKB). Untuk memudahkan memahami penelitian ini, maka didesain model penelitian sebagai berikut: 


\section{Gambar 2. Model Penelitian}

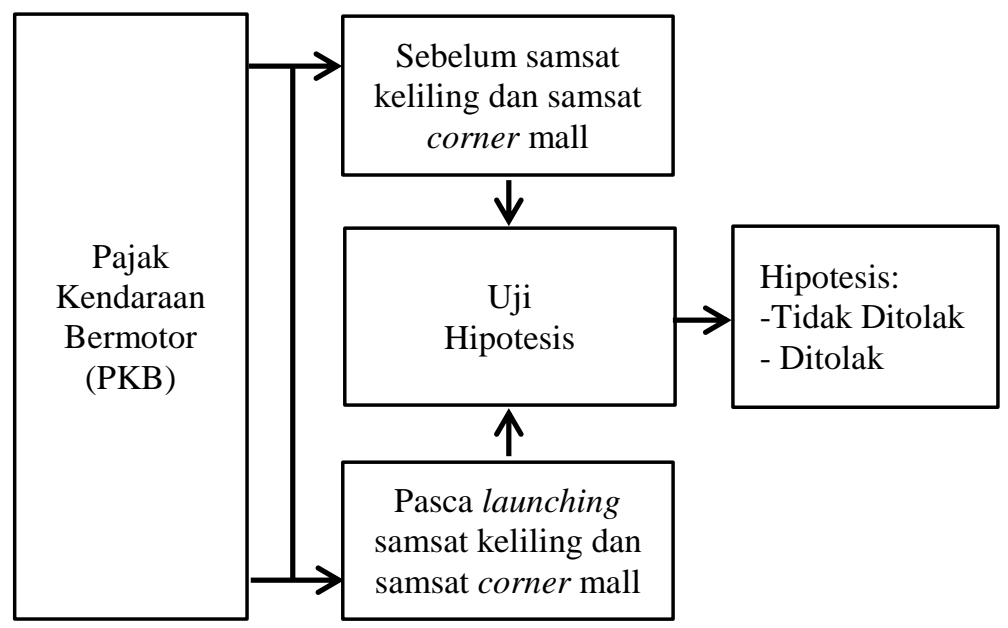

\section{Teknik Analisis Data}

Teknik analisis data adalah uji t sampel berpasangan (related/paired samples $T$ test) berkaitan dengan pengujian hipotesis, digunakan dua variabel independen dan satu variabel dependen.

\section{Hipotesis Penelitian}

Menurut Priyatno (2012), uji t untuk sampel berpasangan (related/paired samples T test) adalah analisis yang digunakan untuk menguji perbedaan rata-rata antara dua sampel yang berpasangan. Sampel yang berpasangan adalah sebuah kelompok sampel dengan subjek yang sama namun mengalami dua perlakuan atau pengukuran yang berbeda, misalnya perlakuan sebelum dan sesudah.

Sebelum dilakukan pengujian hipotesis (Uji t), maka hipotesis yang diajukan adalah sebagai berikut:

$\mathrm{H}$ :1) Diduga ada perbedaan yang signifikan jumlah penerimaan pajak kendaraan bermotor Provinsi Sumatera Selatan sebelum dan pasca launching samsat keliling.

$\mathrm{H}$ :2) Diduga ada perbedaan yang signifikan jumlah penerimaan pajak kendaraan bermotor Provinsi Sumatera Selatan sebelum dan pasca launching samsat corner mall.

\section{HASIL DAN PEMBAHASAN}

\section{Gambaran Umum Penerimaan Pajak Kendaraan Bermotor di Provinsi Sumatera Selatan}

Pajak kendaraan bermotor (PKB), termasuk ke dalam jenis pajak provinsi, yang merupakan bagian dari Pajak Daerah. Adapun target dan realisasi penerimaan pajak kendaraan bermotor di Provinsi Sumatera Selatan, dapat dilihat pada tabel berikut ini.

Tabel 1. Target dan Realisasi Penerimaan Pajak Kendaaran Bermotor (PKB) Provinsi Sumatera Selatan

\begin{tabular}{|c|lr|lc|c|}
\hline Tahun & \multicolumn{2}{|c|}{ Target } & \multicolumn{2}{c|}{ Realisasi } & \% \\
\hline 2016 & $\mathrm{Rp}$ & 1.033 .013 .683 .981 & $\mathrm{Rp}$ & 847.081 .975 .441 & 82 \\
\hline 2017 & $\mathrm{Rp}$ & 850.000 .000 .000 & $\mathrm{Rp}$ & 873.456 .322 .575 & 102 \\
\hline 2018 & $\mathrm{Rp}$ & 878.645 .000 .000 & $\mathrm{Rp}$ & 970.473 .167 .519 & 110 \\
\hline
\end{tabular}

Sumber: Bapenda Provinsi Sumsel (2019)

Berdasarkan tabel 1 di atas, sejak di launching pada bulan April 2017 program pelayanan penghimpunan pajak kendaraan bermotor samsat keliling dan samsat corner mall, memberikan kontribusi yang sangat besar dan menunjukkan peningkatan jumlah penerimaan pajak kendaraan bermotor melebihi pencapaian di atas target-target yang telah ditetapkan oleh Pemerintah Provinsi Sumatera Selatan. 


\section{Analisis Komparatif Sebelum dan Pasca Launching Samsat Keliling Terhadap Penerimaan Pajak Kendaraan Bermotor di Provinsi Sumatera Selatan}

Hasil pengujian diperoleh hasil yaitu, $t_{\text {hit }}$ sebesar 18,799 dan nilai $t_{\text {tabel }}$ 2,201 dengan nilai Sig. (2-tailed) sebesar 0,000 dibawah nilai kritis 0,05 maka diperoleh hasil nilai $\mathrm{t}_{\text {hit }}>\mathrm{t}_{\text {tabel }}(18,800>$ $2,201)$ dan nilai sig $(0,000<0,05)$, sehingga Ho ditolak, artinya terdapat perbedaan jumlah penerimaan pajak kendaraan bermotor di Provinsi Sumatera Selatan sebelum dan pasca dilaunching nya samsat keliling. Dengan demikian hipotesis $\left(\mathbf{H}_{\mathbf{1}}\right)$ yang diajukan diterima. Hasil output Statistical Product and Service Solution (SPSS) dapat dilihat pada tabel dibawah ini:

Tabel 2. Paired Samples Test

\begin{tabular}{|c|c|c|c|c|c|}
\hline & Paired D & erences & \multirow{3}{*}{$\mathrm{t}$} & \multirow{3}{*}{ df } & \multirow{3}{*}{$\begin{array}{c}\text { sig. } \\
\text { (2-tailed) }\end{array}$} \\
\hline & \multicolumn{2}{|c|}{$\begin{array}{c}95 \% \text { Confidence Interval } \\
\text { of the Difference }\end{array}$} & & & \\
\hline & Lower & Upper & & & \\
\hline $\begin{array}{l}\text { Sebelum samsat keliling- } \\
\text { pasca launching samsat } \\
\text { keliling }\end{array}$ & $5.935 \mathrm{E} 10$ & $7.510 \mathrm{E} 10$ & 18,800 & 11 & 0,000 \\
\hline
\end{tabular}

Diperoleh nilai korelasi yaitu, $-0,325$ dengan probabilitas (sig) 0,303 $>0,05$, artinya adanya korelasi sebesar -0,325 mengindikasikan bahwa korelasi antara jumlah penerimaan pajak kendaraan bermotor di Provinsi Sumatera Selatan sebelum dan pasca launching samsat keliling adalah sangat rendah, hal ini mengindikasikan bahwa kesadaran wajib pajak kendaraan bermotor (R2/R4) masih sangat rendah dan tidak taat pajak dengan realisasi pada tahun 2018 sebesar Rp 40.379.914.560 dengan jumlah unit sebanyak 71.458 kendaraan R2/R4. Keadaan ini mengakibatkan jumlah tunggakan pajak kendaraan bermotor R2/R4 meningkat. Hasil output Statistical Product and Service Solution (SPSS) dapat dilihat pada tabel berikut ini.

Tabel 3. Paired Samples Correlations

\begin{tabular}{|l|r|r|c|}
\hline & N & Correlation & Sig. \\
\hline $\begin{array}{l}\text { Sebelum samsat keliling }- \\
\text { pasca launching samsat } \\
\text { keliling }\end{array}$ & 12 & $-0,325$ & 0,303 \\
\hline
\end{tabular}

Analisis Komparatif Sebelum dan Pasca Launching Samsat Corner Mall Terhadap Penerimaan Pajak Kendaraan Bermotor di Provinsi Sumatera Selatan

Berikut hasil pengujian diperoleh hasil yaitu, $t_{\text {hit }}$ sebesar 17,934 dan nilai $t_{\text {tabel }}$ 2,201 dengan nilai Sig. (2-tailed) sebesar 0,000 dibawah nilai kritis 0,05, maka diperoleh hasil nilai $t_{\text {hit }}>t_{\text {tabel }}$ $(17,934>2,201)$ dan nilai sig $(0,000<0,05)$, sehingga Ho ditolak, artinya terdapat perbedaan jumlah penerimaan pajak kendaraan bermotor di Provinsi Sumatera Selatan sebelum dan pasca di-

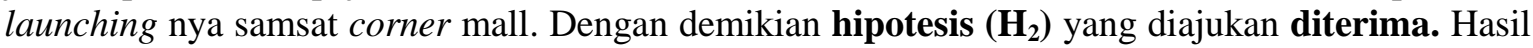
output Statistical Product and Service Solution (SPSS) dapat dilihat pada tabel dibawah ini:

Tabel 4. Paired Samples Test

\begin{tabular}{|c|c|c|c|c|c|}
\hline & Paired D & rences & \multirow{3}{*}{$\mathrm{t}$} & \multirow{3}{*}{ df } & \multirow{3}{*}{$\begin{array}{c}\text { sig. } \\
\text { (2-tailed) }\end{array}$} \\
\hline & \multicolumn{2}{|c|}{$\begin{array}{c}95 \% \text { Confidence Interval } \\
\text { of the Difference }\end{array}$} & & & \\
\hline & Lower & Upper & & & \\
\hline $\begin{array}{l}\text { Sebelum samsat corner } \\
\text { mall - pasca launching } \\
\text { samsat corner mall }\end{array}$ & $5.181 \mathrm{E} 10$ & $6.827 \mathrm{E} 10$ & 17,934 & 11 & 0,000 \\
\hline
\end{tabular}

Diperoleh nilai korelasi yaitu, -0,332 dengan probabilitas (sig) 0,291 >0,05, artinya adanya korelasi sebesar $-0,332$ mengindikasikan bahwa korelasi antara jumlah penerimaan pajak kendaraan bermotor di Provinsi Sumatera Selatan sebelum dan pasca launching samsat corner mall adalah sangat rendah, hal ini mengindikasikan bahwa kesadaran wajib pajak kendaraan 
bermotor (R2/R4) masih sangat rendah dan tidak taat pajak dengan realisasi pada tahun 2018 sebesar Rp 76.295.850.800 dengan jumlah unit sebanyak 74.619 kendaraan R2/R4. Jumlah penerimaan ini lebih besar dibandingkan jumlah penerimaan dari samsat keliling, dikarenakan berada di pusat keramaian (mall) yang menjadi daya tarik bagi wajib pajak untuk membayar pajak kendaraan bermotor. Keadaan ini juga mengakibatkan jumlah tunggakan pajak kendaraan bermotor R2/R4 meningkat. Hasil output Statistical Product and Service Solution (SPSS) dapat dilihat pada tabel berikut ini.

Tabel 5. Paired Samples Correlations

\begin{tabular}{|l|r|r|c|}
\hline & N & Correlation & Sig. \\
\hline $\begin{array}{l}\text { Sebelum samsat corner mall } \\
\text { - Pasca lauching samsat } \\
\text { corner mall }\end{array}$ & 12 & $-0,332$ & 0,291 \\
\hline
\end{tabular}

\section{DAFTAR PUSTAKA}

[1]. Agoes, Sukrisno, dan Estralita Trisnawati. 2013. Akuntansi Perpajakan. Edisi 3. Jakarta: Penerbit Salemba Empat.

[2]. Halim, Abdul, Icuk Rangga Bawono, dan Amin Dara. 2014. Perpajakan: Konsep, Aplikasi, Contoh dan Studi Kasus. Jakarta: Penerbit Salemba Empat

[3]. Priyatno, Duwi. 2012. Cara Kilat Belajar Analisis Data dengan SPSS 20. Yogyakarta:Penerbit Andi.

[4]. Sambodo, Agus. 2015. Pajak Dalam Entitas Bisnis. Jakarta: Penerbit Salemba Empat.

[5]. Waluyo. 2008. Perpajakan. Buku 1 Edisi 8. Jakarta: Penerbit Salemba Empat.

[6]. Republik Indonesia, Undang-Undang Nomor 33 Tahun 2004 Tentang Perimbangan Keuangan Antara Pemerintah Pusat dan Pemerintahan Daerah.

[7]. Republik Indonesia, Undang-Undang Nomor 28 Tahun 2007 Tentang Ketentuan Umum dan Tata Cara Perpajakan

[8]. Republik Indonesia, Undang-Undang Nomor 28 Tahun 2009 Tentang Pajak Daerah dan Retribusi Daerah.

[9]. Pemerintahan Provinsi Sumatera Selatan, Peraturan Daerah Nomor 3 Tahun 2011 Tentang Pajak Daerah dan Retribusi Daerah.

[10]. Pemerintahan Provinsi Sumatera Selatan, Peraturan Gubernur Nomor 11 Tahun 2012 Tentang Pajak Daerah dan Retribusi Daerah

[11]. https://id.wikipedia.org/wiki/Sistem_administrasi_manunggal_satu_atap 